\title{
Contemporary Graphic Arts: Synthesis of the Creation Process for Products with Cultural Dimensions
}

\author{
Kanokwan Nithirattapat ${ }^{1}$, Songkoon Chantachon ${ }^{1} \&$ Marisa Koseyayothin ${ }^{2}$ \\ ${ }^{1}$ The Faculty of Cultural Science, Mahasarakham University, Khamriang Sub-District, Kantarawichai District, \\ Maha Sarakham, Thailand \\ ${ }^{2}$ Kanchanapisek Non-Formal Education Centre (Royal Academy), Salaya Sub-District, Bhuttamonthon District, \\ Nakhon Pathom, Thailand \\ Correspondence: Nuengruethai Coulson, 391/12 Moo 5, Nongchang Sub-District, Nongchang District, Uthai \\ Thani, Thailand. E-mail: david.coulson.6@gmail.com
}

Received: January 27, 2013 Accepted: February 19, 2013 Online Published: March 28, 2013

doi:10.5539/ass.v9n4p140 URL: http://dx.doi.org/10.5539/ass.v9n4p140

\begin{abstract}
Contemporary graphic arts in Thailand are becoming diluted by lack of development and continued western influence. This qualitative research discusses the history of contemporary graphic arts in Thailand with the aim of identifying a synthesis of artwork creation. Thai art and, specifically Thai graphic art, has a richly multicultural history. Without western influence, the art-form would not enjoy its currently exalted national reputation. Regardless, the production techniques are becoming thinned and stagnant and there is a need to develop contemporary graphic art, so to retain a strictly Thai identity for modern generations to enjoy and cherish. This article addresses the cultural considerations of the creation process and identifies areas in which the field can be developed for a prosperous and unique future.
\end{abstract}

Keywords: graphics, art, contemporary, cultural dimension, creativity, arts, synthesis, dynamic

\section{Background}

Art has been a fixture of society from past to present and, as such, there have been many attempts at defining it: 'a natural imitation', 'a universal connector among humans', 'performance of beauty', 'a language', 'trust and belief in each era', and 'imagination transfer'. Art can accurately be referred to as multi-faceted human creation depicting appreciation, impression and sorrow according to individual talent for reproducing beauty and applying pressure (Atthapak, 2007, p. 9).

Art is divided into two fields. Visual art is a branch of art which includes artwork that emphasizes beauty and spiritual values rather than utility. Fine art includes music, dance, architecture and literature. Visual art also consists of painting, sculpture and graphic art. Ancient Siamese artwork was recorded in words, paintings and photographs, all of which tell the history of Thai art and culture. These give a clear indication as to the identity of Thai people, which has prospered and evolved according to cultural change. Thus, contemporary arts have evolved in terms of forms and ideas. Graphic Arts or Graphics is a field of arts that occurred through creative picture processing from moulds (Lisuwan, 1988, pp. 81-94).

In the past, humans transferred and exchanged ancient cultures. In particular, valuable national artwork was exchanged from East to West and West to East (Lisuwan, 1988, p. 17). It was this multicultural transfer that really enabled Thai art to flourish in the early part of the twentieth century. Italian national Corrado Feroci immigrated to Thailand by invitation in 1923 to instruct students in sculpture at the Fine Arts Department of the Ministry of Palace Affairs. With this as his base, Feroci transformed the image of modern Thai art and directly influenced the creation of some of the nation's most iconic landmarks, including Democracy Monument, Victory Monument and the statue of King Rama I at Memorial Bridge. Feroci also founded the most famous arts university in Thailand in 1943. Later, after Feroci changed his name to Silpa Bhirasri in 1944 in fear of hostile treatment from invading Japanese soldiers during World War Two, the university was officially renamed Silpakorn University (Wongubarat, 1978).

Silpakorn is just one of a number of institutions operating in Thailand for the study of art, such as POH-CHANG Academy of Arts, Chulalongkorn University, Burapha University, Bangkok University and Rangsit University 
(Phungamdee, 2004, p.9). Besides these, there are exhibitions for art lovers and people interested in art at art galleries, restaurants and hotels. These reflect the power of beautiful work that has aesthetic value and portrays lifestyle, society, religion, politics and rules. These are all cultural trends that influence the concepts of professors teaching in universities and schools, ensuring that Thai art continues to evolve.

\section{Research Aims and Methodology}

The researchers developed knowledge and understanding of contemporary graphic arts and transferred this knowledge by exchanging experience, concepts, work creation methods, models and presentations. The results of this research reflect the importance of cultural influence that has been applied together with the creative intuition of artists to develop art.

The aims of this research were threefold: a) to study the history of contemporary graphic arts in Thailand; b) to study the techniques applicable for the creation of artwork that reflects cultural influences; c) to study a synthesis of artwork creation.

The researcher collected information through field study and literature review, survey, participatory and non-participatory observation, questionnaire and interviews with art maestros in Thailand, art experts, art students, artists, art professors and other experts in three provinces. The studied samples were seventy-five data providers from Silpakorn University in Bangkok, Chiang Mai University in Chiang Mai, and Mahasarakham University in Mahasarakham. This research project started in December 2011 and continued until December 2012. The data obtained was verified using a triangulation technique before being analyzed in accordance with the research objectives. The results from the research are presented as a descriptive report.

\subsection{Importance of the Research}

The results of this research will benefit related art organizations and can be applied in education as a model of creative research in art offices or organizations. The results of this research reflect cultural influences on contemporary graphic arts in each era and develop knowledge and understanding about contemporary graphic arts. The researchers developed knowledge and understanding about dynamic contemporary graphic art and transferred, exchanged and learned the processes of creative work through interviews with informants and artists. The results of this research reflect valuable culture through creative processes and models in various ways. These can be resources for further study.

\section{Results}

The creation process for graphic art, a branch of fine art, begins with the production of the plate that will be used on the canvas or paper or any other base. A plate is used to create multiple and identical copies of the artwork. During the Sukhothai and Ayutthaya periods of Thai history, printed artwork was used in governmental seals. The printing press was first used in Thailand under the commission of King Narai the Great. Emphasis was placed upon the publishing of books. In the first era, the plate was carved from wood, but was soon replaced by plates made from metal and stone. In the reign of King Rama VI, the printed art or graphic art in Thailand was created by Silpa Bhirasri, the Father of Modern Arts and the founder of Silpakorn University in 1943, although it was not named Silpakorn University until 1944. This university was the first art institute in Thailand to teach western art creation techniques. Graphic arts were first created by students of this university. Honored Professor Chalood Nimsamer was another key figure in the history of graphic art in Thailand. Laying the foundations of knowledge in the subject, he proposed that graphic art should be included in the curricula of the university. Professor Chalood Nimsamer is regarded as 'The Father of Graphic Arts in Thailand' by Thai graphic artists.

The creation of graphic art can be categorized into four main processes, namely, relief process, intaglio process, planographic process and serigraphic process. These four processes are fundamental techniques found in graphic art. They are key tools that artists use for reflecting their ideas. Currently, artist work schemes can be classified into two types, namely the conservative scheme and the contemporary scheme. The conservative scheme is where artists use conventional techniques used by other artists of the same genre in order to reflect their ideas on paper through various high quality and technical processes such as etching, lithograph, and mezzotint. The contemporary scheme emphasizes ideas and innovative materials and technologies such as 3D art, conceptual art, computer art and installation.

In conclusion, contemporary graphic artists emphasize ideas and techniques that lead to innovative and creative artworks such as water color mono-print and lithography on wood. Artists are free to create their work via both conservative and contemporary schemes. The renowned graphic artists of the current era are Yanwit Kunjaethong, Manee Meemak, Tinnakorn Kasornsuwan, Amnaj Kongwaree, Kamolpan Chotvichai, Parichart Suphaphan, Phongsiri Kiddee, Kuntalee Tuntittavewat, Boonmee Sangkhum and Patcha Kaewtongtal. The artwork of each 
artist reflects the individualism and identity of its creator, using appropriate techniques that convey ideas and emotions, as well as mental needs. Modern Thai artists use appliances and information technology to create their artwork. Thus, their work is equivalent to those created by internationally renowned artists. This equivalence leads to the linkage and exchange of ideas and knowledge on art, which changes artwork according to the era and reflects the globalized contemporary concepts of Thai art.

\section{Discussion}

Changing society stems from the changing relationships of people within that society. One classic example of this is the relationship between rural residents and city dwellers. Relationship changes are common, whether they are between family members, relatives, acquaintances or strangers. The largest influencing factors are politics and economy, which are the most likely aspects of the local environment to change dramatically on a regular basis.

The components of living in groups, in the same area, adopting the same concepts are how humanity develops. By sharing advantages, disadvantages, experiences and motivation, humans identify ideals and preferences. This is no different for art and artists. By sharing their local customs, culture and artistic heritage, Isan artists, as one example, present Isan art to newer generations and wider audiences, who can then learn and perform these arts within their own communities and societies, even on a global scale. Thus, artistic culture modernizes.

Culture reflects social growth, tradition, morals and lifestyle through the creation of materials, objects, behaviors, concepts, processes and work systems. Art is a perfect medium for the transfer of culture as can include all of these. Arts can be aesthetically impressive, they can be two or three-dimensional, they can be based on value, beauty, religion belief or society. These are the factors that meet the needs of human minds and emotions. They are all to be found in art and sculpture.

Contemporary graphic art in Thailand reflects cultural dimensions, the period of Thai society, the changes in Thai society and culture through graphic arts presentation, the process of transferring knowledge from teachers, arts or work experience. At present, artists employ contemporary graphic arts more than in previous generations. Their forms include conceptual art, installation art, land art, body art and performance art.

In the past, art could be seen in the temples or at royal palaces, which reflected how art was both familiar with religion and created for country rulers. Then, the trends of the West came to Thailand in the form of Silpa Bhirasri and changed art education. The creation of new and modern art, the changes of presentation forms, materials, work creation and also exhibitions supported by the government and the private sector now occur much more than in the past.

\subsection{History and Background of Contemporary Graphic Arts in Thailand}

In the past, photographic prints were used as stamps, reference manuals and books but were not yet used as visual art for decoration of walls. This is in correspondence with the research of Kamon Kongthong, who studied graphic arts in Thailand from 1960 to 1993 (1994, pp. 354-357). Kongthong found that the origins of graphic art in Thailand were outside of the country and that the techniques were only imported in with the immigration of foreign nationals. The original models of Thai graphic art for use in books were created from wood. The influence of Silpa Bhirasri, originally of Italy, was the reason for a modernization in graphic art models. Additionally, Bhirasri oversaw the increase of governmental and private financial support for art as well as the adoption of new, western creative techniques and standards, through his artistic base at (the subsequently named) Silpakorn University.

During Bhirasri's time, abstract art began to be used by Thai artists and the students were taught at an unprecedented educational standard for Thailand. Indeed, after Silpa Bhirasri passed away in the year 1962, many of his former students continued to receive arts awards and prizes. Although Bhirasri was arguably the starting point of an art revolution in Thailand, it was his many students who spread the teachings so thoroughly after his death. Using examples such as this, Niyapan Wansiri (1997, pp. 99-101) is able to argue that globalization originates from many centres. Each centre will have different cultural practices and nuances, including the individual artistic principles of Bhirasri's students, but through mix and interchange of techniques, global society will grow.

\subsection{Past techniques for Graphic Art Creation}

In the past there were study and teaching techniques for printing on stone, ceramics, wood and landscapes. The medium with the greatest number of problems was stone. Research was conducted into ways of solving the problems with stone print creation by Kanya Chareonsupkul (1991, pp. 15-16). This research found that there remained many experts of stone printing in Thailand. In the past the stamps were created from limestone but, 
nowadays, aluminum is increasingly prevalent. This is due to the fact that the best quality limestone is too large and difficult to maneuver. This resulted in a number of courses opening in universities across the country to find techniques to conserve, develop and continue the art-form into the modern world and is a technique that must be applied to other art-forms in the country to prevent them from dying out.

The research of Mello, Jung and Walter (2007, pp. 1-8) aimed to solve the problems with creation of images by studying virtual woodcuts in order to help with the management of automatic image synthesis on computer. This research supported the idea of experimentation to create work techniques and concerned the material, weight and style of print stamps. It is with such techniques and innovations that the art profession must modernize to ensure the continuation of their trade in modern society.

\subsection{Contemporary Graphic Arts: Synthesis of the Creation Process for Products with Cultural Dimensions}

Sakon Phungamdee (2004) found that human beings surmise value of aesthetic and material beauty from nature and that which they have created. The assessment of aesthetic value revolves around the actual beauty of the material, the aesthetic feeling of the observer, including the meaning of the piece and satisfaction with the aesthetics, material and mental characteristics of natural aesthetics, origin and nature of the artistic motivation and the underlying theory of the visual art.

Mai Thatiya (2004, pp. 53-54) found that the principles of visual recognition from external human contact and observation of artwork are based on colorful and beautiful shapes. The artists see value through a combination of visual observation and inner feeling. People who have evolved and inherited this ability to recognize and feel art are able to produce unique forms of art. These differences are determined by the philosophy, beliefs, experience, knowledge and inspiration of the artist.

Art in Thailand is a key to conserving and continuing the rich cultural heritage that the country has enjoyed over the years. Specifically for this study, graphic art must be recognized as a medium to combat unified globalization of techniques and the dilution of Thai standards. Although acknowledgement must be given to the multicultural influence in the Thai graphic art revolution, techniques and education must be improved to ensure that the Thai art community retains its pluralism and is respected by future generations.

\section{References}

Atthapak, C. (2007). Art Composition. Bangkok: Wittayapat.

Chareonsupkul, K. (1991). Possibilities of Lithograph Making in Thailand. Bangkok: Ammarin Printing Group and Publishing Plc.

Kongthong, K. (1994). Evolution of Printed Art in Thailand from 1960 to 1993. Bangkok: Sri Nakkarin Tarawirot University.

Lisuwan, W. (1988). Interesting Elements of Art. Bangkok: Odien Store.

Mello, V. T., Jung, C. R., \& Walter, M. (2007). Virtual Woodcuts from Images. In Proceedings of the $5^{\text {th }}$ International Conference on Computer Graphics and International Techniques in Australia and Southeast Asia. Western Australia: The Great Fine Art Company

Phungamdee, S. (2004). Background Opinion of Art. Bangkok: Bookpoint.

Thatiya, M. (2004). Aesthetics of Visual Art. Bangkok: Watsin Printers.

Wasiri, N. (1997). Humanity, Society and Culture. Bangkok: Kasetsart Printing.

Wongubarat, D. (1978). Professor Silpa Bhirasri. Bangkok: Banya. 